\title{
MECHANICAL PROPERTIES OF EXTRUDED MIXED COMPONENTS BASED ON ALUMINUM POWDERS AND TERNARY ALUMINUM-CONTAINING INTERMETALLIC COMPOUNDS SYNTHESIZED BY VARIOUS METHODS
}

\author{
Mikhail TROTSKY, Sergey PETROVICH, Maxim ZAMOZDRA \\ Peter the Great St. Petersburg polytechnic university, St.Petersburg, Russian Federation, \\ m trotsky.ru@mail.ru
}

https://doi.org/10.37904/metal.2020.3603

\begin{abstract}
This work is devoted to the study of the synthesis of various ternary intermetallic compounds based on aluminum in two alternative ways - self-propagating high-temperature synthesis (SHS) and mechanosynthesis (MS) and subsequent hot extrusion (HE) of pure aluminum powder mixtures as a matrix and the abovementioned TIM as a hardening additive. Mechanical tensile tests showed an increase in tensile strength by 3.3 $-9.7 \%$ rel. (Except for one specimen, which stands out from the others) and an increase in microhardness by $9.3-49.1 \%$. The microstructure analysis shows a uniform distribution of hardening particles over the matrix volume, which indicates a high uniformity of the distribution of TIM based on aluminum in the aluminum matrix.
\end{abstract}

Keywords: Hot extrusion of aluminum, intermetallic compounds, dispersed hardening, mechanosynthesis, powder metallurgy

\section{INTRODUCTION}

Powder metallurgy opens up wide possibilities for creating artificial ("synthetic") alloys, strengthened by double or triple IM, which can be realized by introducing pre-synthesized IM powders of a given chemical composition into pure aluminum (as well as other metals) powders or its low-alloyed alloys. As a result of such an introduction, the system will significantly differ from the equilibrium one and will contain significantly more than in accordance with classical phase diagrams, the number of strengthening phases. This content is determined only by the interests of the researcher, aimed at obtaining the best set of strength and service characteristics of the material after thermoplastic processing of the mixtures [1-3]. Triple intermetallic (TIM) compounds are found in many industrial alloys based on aluminum Aluminium and have a significant influence on their properties. They can be present in a structurally free state, enter the eutectic structure, or be in the form of scattered particles released during the dispersive decay of quenched alloys. One of the methods for producing aluminum-based intermetallic compounds, in addition to mechanosynthesis, is self-propagating hightemperature synthesis (SHS) of solid chemical compounds - a technological process for producing materials based on an exothermic chemical reaction of the interaction of the starting reagents in the form of combustion [4-6].

In this research, we study the patterns of the formation of ternary intermetallic compounds in various ways and their effect on aluminum alloys.

\section{MATERIALS, METHODS AND DISCUSSION}

\subsubsection{Synthesis of $\mathrm{Al}-\mathrm{Ti}-\mathrm{Zn}$ systems}

The synthesis was carried out according to a multistage scheme, including the mixing of titanium and aluminum powders, pressing the mixture, synthesis of the $\mathrm{Al}_{3} \mathrm{Ti}$ intermetallic compound by SHS in vacuum. From the 
finished mixture, tablets $\varnothing 30 \mathrm{~mm}$ and a height of $10 \mathrm{~mm}$ were pressed at a pressure of $300 \mathrm{MPa}$. During SHS, a high-speed character of the $\mathrm{Al}_{3} \mathrm{Ti}$ formation reaction was noted: after slow heating to $370 \mathrm{~K}$ for 160 minutes, the temperature of the space inside the retort rose to $1165 \mathrm{~K}$ within 10 minutes. The resulting material is an uneven structure consisting, according to the XRD data, of $70 \% \mathrm{Al}_{3} \mathrm{Ti}$, the rest are oxides. From powders of 88.4Al-11.6Zn alloy (wt\%), Zinc and synthesized $\mathrm{Al}_{3} \mathrm{Ti}$ (all fractions 0 - $63 \mu \mathrm{m}$ ), batch mixtures corresponding to the stoichiometry of $\mathrm{TIM} \mathrm{Al}_{11} \mathrm{Ti} \mathrm{i}_{4} \mathrm{Zn}$ and $\mathrm{Al}_{66} \mathrm{Ti}_{25} \mathrm{Zn}_{9}$ were prepared.

\subsubsection{Synthesis of TIM systems of Al-Mg-X systems (where $\mathrm{X}-\mathrm{Mn}, \mathrm{Cr}$ )}

The mixture corresponding to the stoichiometry of $\mathrm{TIM} \mathrm{Al}_{18} \mathrm{Mg}_{3} \mathrm{Cr}_{2}$ was prepared from powders of aluminum, PAM aluminum - magnesium alloy, and Al- $\beta \mathrm{Cr}$ alloy powder (all fractions are 0-63 $\mu \mathrm{m}$ ). A mixture corresponding to the stoichiometry of $\mathrm{TIM} \mathrm{Al}_{18} \mathrm{Mg}_{3} \mathrm{Mn}_{2}$ was prepared from powders of aluminum, aluminummagnesium alloy, and Al-27Mn alloy powder (all fractions 0-63 $\mu \mathrm{m}$ ). Pressing tablets and conducting SHS repeated the procedure described in 2.1.1. The system was heated uniformly to a temperature of $330 \mathrm{~K}$ (in the fore vacuum). A possible temperature jump, due to which it would be possible to judge the high energy release during the synthesis of $\mathrm{Al}-\mathrm{Mg}-\mathrm{X}$ TIM was not observed, in contrast to the $\mathrm{Al}-\mathrm{Ti}-\mathrm{Zn}$ synthesis. However, the obtained samples were very different from the original tablets: in addition to colour changes, the volume of tablets increased by 1.5 times. The XRD of the initial and obtained samples revealed the presence of various phases and their conversion from one to another during SHS (Table 1 and Table 2).

\subsubsection{Synthesis of TIM system Al-Mg-Cr}

During SHS, a new TIM ( $\left.\mathrm{Al}_{18} \mathrm{Mg}_{3} \mathrm{Cr}_{2}\right)$ was synthesized, content of which amounted to $37 \%$ according to the XRD results. One can notice a sharp decrease in the aluminum content (almost three times) and complete dissolution of the phases $\mathrm{Al}_{12} \mathrm{Mg} 17, \mathrm{Al}_{8} \mathrm{Cr}_{5}$ and $\mathrm{Al}_{18.26} \mathrm{Cr}_{4}$, which during the synthesis were transformed into $\mathrm{Al}_{18} \mathrm{Mg}_{3} \mathrm{Cr}_{2}$ and $\mathrm{Al}_{45} \mathrm{Cr}_{7}$ (Table 1). SHS significantly changed (Figure 1) the diffraction patterns of the test sample.

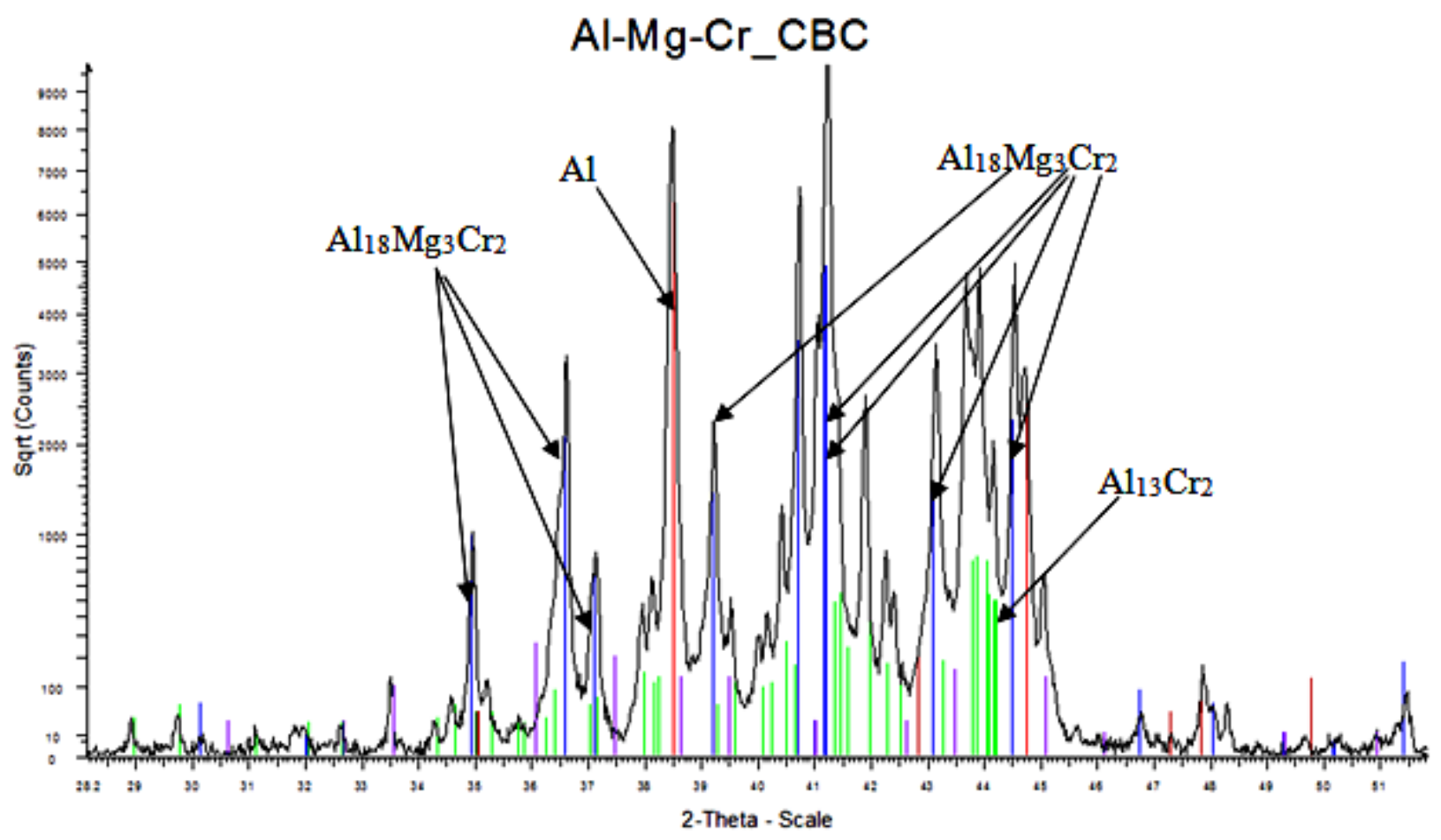

Figure 1 Diffraction patterns of the material of the Al-Mg-Cr system obtained as a result of SHS 
Table 1 Comparison of the initial mixture of Al-Mg-Cr and the sample obtained by SHS

\begin{tabular}{|c|c|c|c|}
\hline \multicolumn{2}{|c|}{ Powder sample } & \multicolumn{2}{c|}{ SHS sample } \\
\hline Phase & Content (wt\%) & Phase & Content (wt\%) \\
\hline $\mathrm{Al}$ & 59.1 & $\mathrm{Al}$ & 20.3 \\
\hline $\mathrm{Al}_{12} \mathrm{Mg}_{17}$ & 25.7 & $\mathrm{Al}_{18} \mathrm{Mg}_{3} \mathrm{Cr}_{2}$ & 37.4 \\
\hline $\mathrm{Al}_{8} \mathrm{Cr}_{5}$ & 12.3 & $\mathrm{Al}_{13} \mathrm{Cr}_{2}$ & 42.2 \\
\hline $\mathrm{Al}_{18.26} \mathrm{Cr}_{4}$ & 2.7 & & - \\
\hline
\end{tabular}

Table 2 Comparison of the initial mixture of Al-Mg-Mn and the sample obtained by SHS

\begin{tabular}{|c|c|c|c|}
\hline \multicolumn{2}{|c|}{ Powder sample } & \multicolumn{2}{|c|}{ SHS sample } \\
\hline Phase & Content (wt\%) & Phase & Content (wt\%) \\
\hline $\mathrm{Al}$ & 30.8 & $\mathrm{Al}$ & 10.8 \\
\hline $\mathrm{Al}_{12} \mathrm{Mg}_{17}$ & 37.6 & $\mathrm{Al}_{12} \mathrm{Mg}_{17}$ & 32.8 \\
\hline $\mathrm{Al}_{6} \mathrm{Mn}$ & 19.8 & $\mathrm{Al}_{6} \mathrm{Mn}_{1}$ & 32.8 \\
\hline $\mathrm{Al}_{10} \mathrm{Mn}{ }_{3}$ & 2.3 & $\mathrm{Al}_{18} \mathrm{Mg}_{3} \mathrm{Mn}_{2}$ & \\
\hline $\mathrm{alpha}-\mathrm{Mn}$ & 1.9 & & - \\
\hline $\mathrm{Al}_{57} \mathrm{Mn} 12$ & 7.3 & & - \\
\hline
\end{tabular}

\subsection{Obtaining TIM based on aluminum by mechanosynthesis (MS)}

The batch was prepared in the same proportions as described in the materials of Chapter 2.1.2. The batch mechanosynthesis was carried out in the attritor according to the procedure with steel balls $\varnothing 7-10 \mathrm{~mm}$ weighing $20 \mathrm{~kg}$ per $1150 \mathrm{~g}$ of powder mixture. Each powder mixture was processed for $8 \mathrm{ks}$. The MS mode was selected as follows: after $1 \mathrm{ks}$ ( $16 \mathrm{~min}$ and $40 \mathrm{sec}$.), The machining took a break of 30 minutes to cool the system. Before the start of the MS and after every $2 \mathrm{ks}$ of machining, a sample was taken and surfactant was added (0.6 wt \% Stearic acid).

Diffraction patterns of the Al-Mg-Mn system are presented in Figure 2.

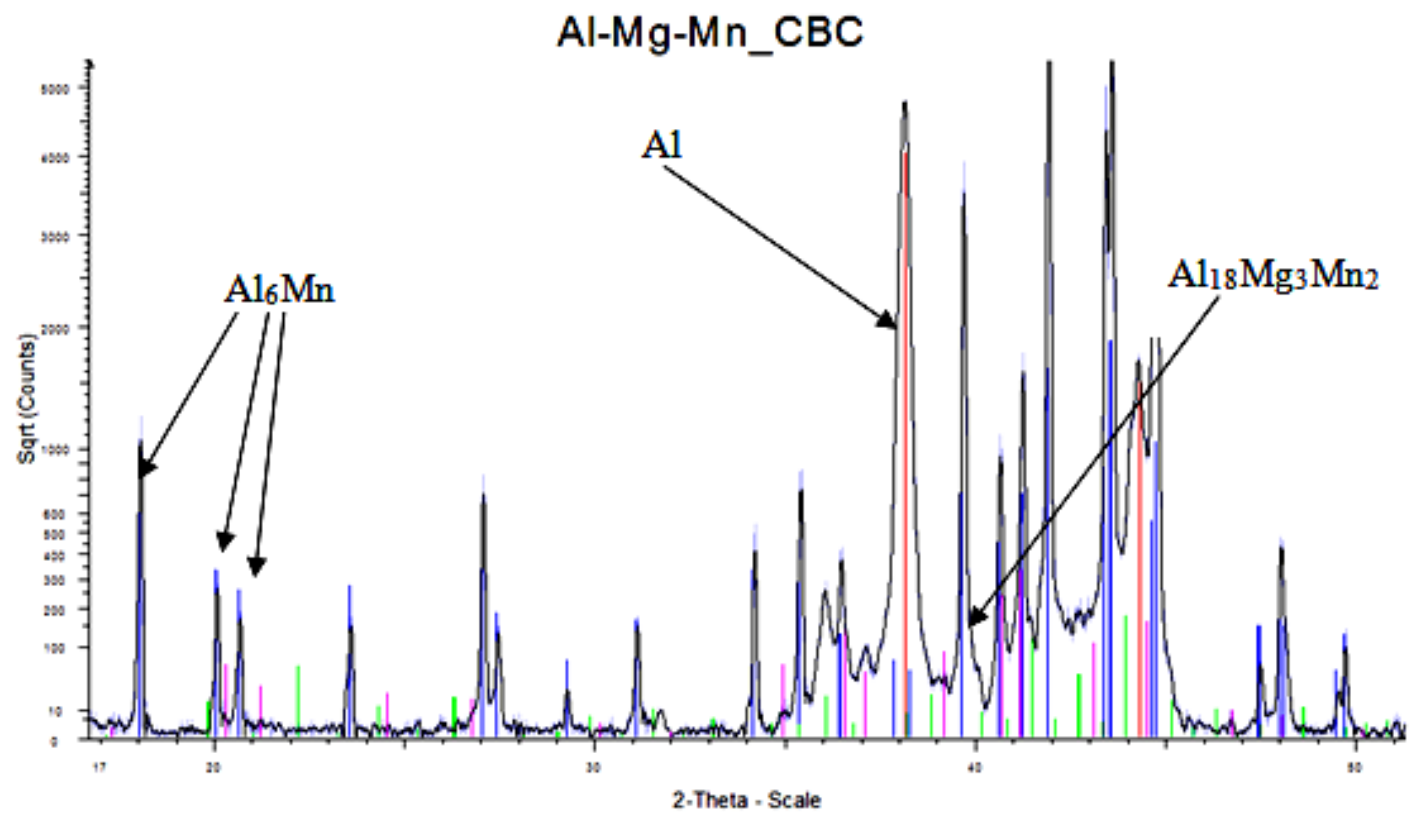

Figure 2 Diffraction patterns of the material of the Al-Mg-Mn system obtained as a result of SHS 


\subsubsection{Synthesis of Al-Ti-Zn Systems}

The diffraction patterns of the TIM mixture powder corresponding to $\mathrm{Al}_{66} \mathrm{Ti}_{25} \mathrm{Zn}_{9}$ and $\mathrm{Al}_{11} \mathrm{Ti}_{4} \mathrm{Zn}$ at different activation times are shown in Figure 3 and Figure 4. During the high-energy MS, the occurrence and constant, up to 74 wt. \%, increase in the content of IMT $\mathrm{Al}_{66} \mathrm{Ti}_{25} \mathrm{Zn}_{9}$. A similar increase in the content of IMT $\mathrm{Al}_{11} \mathrm{Ti}_{4} \mathrm{Zn}$ was $54 \%$.

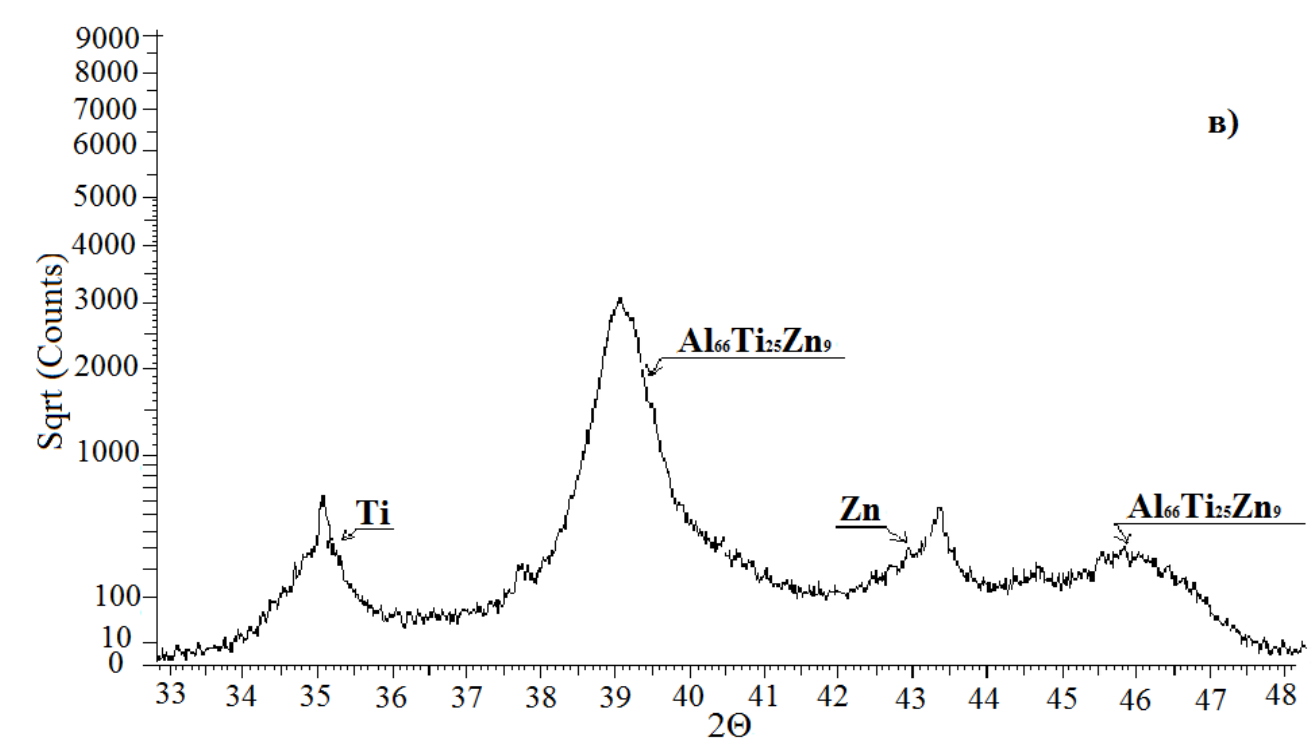

Figure 3 The diffractogram of the charge corresponding to the intermetallic $\mathrm{Al}_{66} \mathrm{Ti}_{25} \mathrm{Zn}_{9}$ (the content of which is $74 \%$ )

Using SEM, the distribution of elements was definitely determined in the form of a finely dispersed structure, which is a homogeneous compound of aluminum, titanium, and zinc in concentrations corresponding to the composition of TIM Ti25Zn9Al66 (Figure 5).

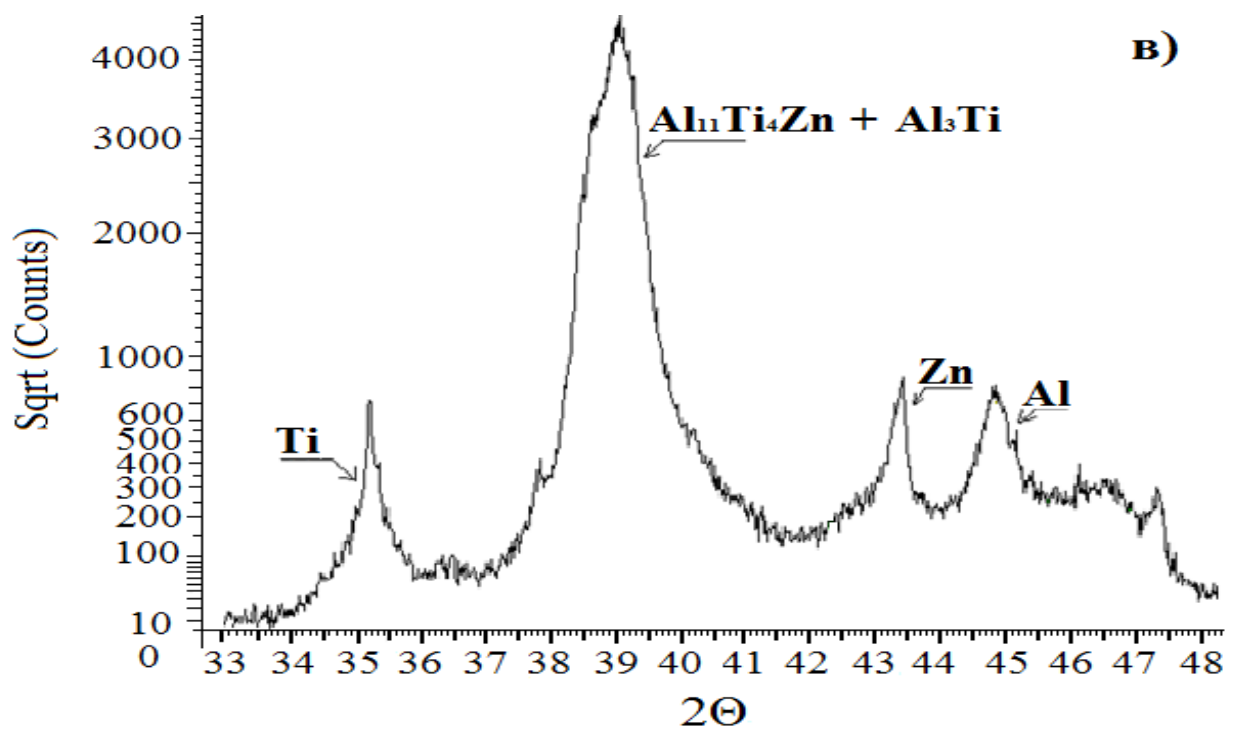

Figure 4 The diffraction pattern of the mixture corresponding to the intermetallic $\mathrm{Al}_{11} \mathrm{Ti}_{4} \mathrm{Zn}$ (the content of which is $54 \%$ )

As a result of the work according to the results of Chapter 2.1 and Chapter 2.2, new TIM-containing powders were synthesized, the phase composition of which is given in Table 3. 
Table 3 The phase composition of the powders during the synthesis of TIM after the SHS and MS methods

\begin{tabular}{|c|c|c|c|c|c|c|c|c|c|}
\hline \multirow{2}{*}{$\begin{array}{l}\text { Stage } \\
\text { number }\end{array}$} & \multirow{2}{*}{$\begin{array}{l}\text { Synthesis } \\
\text { method }\end{array}$} & \multirow{2}{*}{ Main phase } & \multirow{2}{*}{$\begin{array}{c}\text { TIM content } \\
(\%)\end{array}$} & \multicolumn{6}{|c|}{ Other phases (\%) } \\
\hline & & & & Al & $\mathrm{Al}_{13} \mathrm{Cr}_{2}$ & $\mathrm{Al}_{12} \mathrm{Mg}_{17}$ & $\mathrm{Al}_{6} \mathrm{Mn}$ & Zn & $\mathrm{Al}_{3} \mathrm{Ti}$ \\
\hline 1 & SHS & $\mathrm{Al}_{18} \mathrm{Mg}_{3} \mathrm{Cr}_{2}$ & 37 & 20 & 43 & - & - & - & - \\
\hline 2 & SHS & $\mathrm{Al}_{18} \mathrm{Mg}_{3} \mathrm{Mn}_{2}$ & 34 & 23 & - & 11 & 32 & - & - \\
\hline 3 & MS & $\mathrm{Al}_{11} \mathrm{Ti}_{4} \mathrm{Zn}$ & 53 & 24 & - & - & - & 9 & 14 \\
\hline 4 & MS & $\mathrm{Al}_{66} \mathrm{Ti}_{25} \mathrm{Zn}_{9}$ & 75 & 14 & - & - & - & 4 & 7 \\
\hline
\end{tabular}
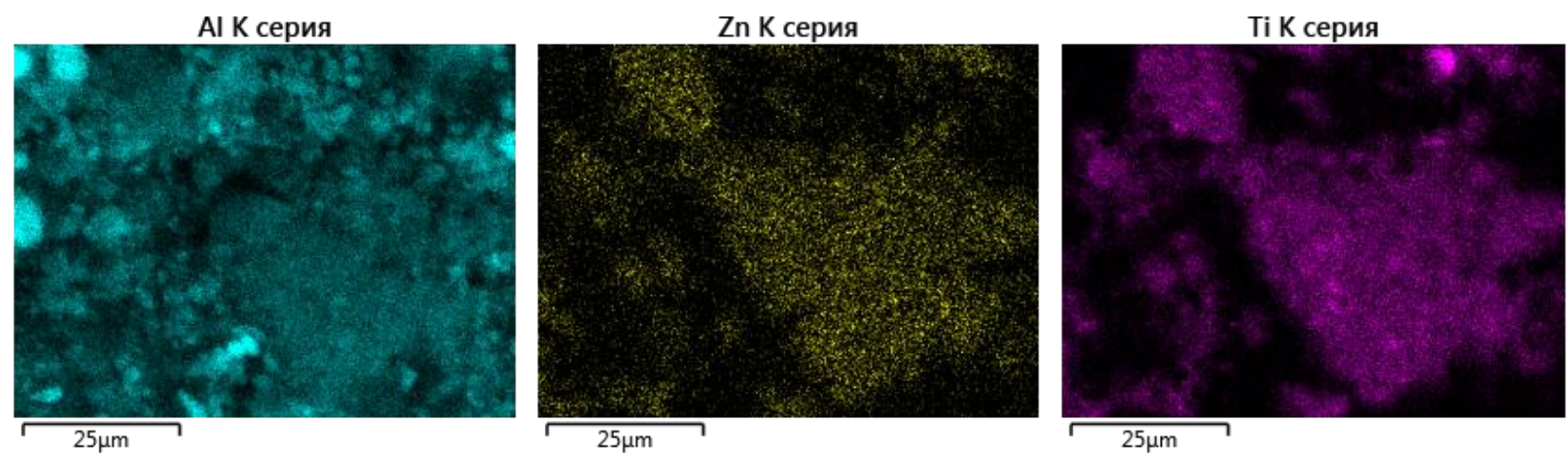

Figure 5 SEM image of the intermetallic compound $\mathrm{Ti}_{25} \mathrm{Zn}_{9} \mathrm{Al}{ }_{66}$

\subsection{Obtaining compact semi-finished products by the method of GE powder mixtures}

Hot extrusion of powders containing TIM phases obtained by performing steps 1 and 2 of this work was carried out in the following sequence 2.3.1 and 2.3.2:

\subsubsection{Preparation of a mixture of unalloyed aluminum powder and TIM - containing powder}

The calculation of the required amount of TIM-containing phase from Table 3 was made in such a way that the mass of "pure" TIM was $3 \mathrm{~g} / 100 \mathrm{~g}$ of the charge ( $3 \mathrm{wt} \%$ ) (Table 4).

Table 4 Preparation and creation of blends Al + TIM

\begin{tabular}{|c|c|c|c|c|c|c|}
\hline TIM & $\begin{array}{c}\text { The initial } \\
\text { number of } \\
\text { TIM in the } \\
\text { samples (\%) }\end{array}$ & $\begin{array}{c}\text { The required } \\
\text { amount in } \\
\text { the mixture } \\
(\%)\end{array}$ & $\begin{array}{c}\text { The total } \\
\text { mass of the } \\
\text { mixture (g) }\end{array}$ & $\begin{array}{c}\text { \% TIM of the } \\
\text { total mass }\end{array}$ & $\begin{array}{c}\text { Mass TIM } \\
(\mathrm{g})\end{array}$ & $\begin{array}{c}\text { Al powder } \\
\text { mass } \\
\text { (g) }\end{array}$ \\
\hline $\mathrm{Al}_{18} \mathrm{Mg}_{3} \mathrm{Cr}_{2}$ & 34 & 3 & 120 & 3.6 & 10.9 & 109.1 \\
\hline $\mathrm{Al}_{18} \mathrm{Mg}_{3} \mathrm{Mg}_{2}$ & 37 & 3 & 120 & 3.6 & 9.7 & 110.3 \\
\hline $\mathrm{Al}_{66} \mathrm{Ti}_{25} \mathrm{Zn}$ & 75 & 3 & 120 & 3.6 & 4.8 & 115.2 \\
\hline $\mathrm{Al}_{11} \mathrm{Ti}$ & $3 \mathrm{Zn}$ & 53 & 120 & 3.6 & 6.7 & 113,3 \\
\hline
\end{tabular}

\subsubsection{Cold pressing of blends and auxiliary tablets of graphite}

Briquetting the mixture into tablets took place under the same conditions for all powders: matrix diameter 30 $\mathrm{mm}$, pressing pressure - $200 \mathrm{MPa}$. The process was as follows: a replaceable die, a graphite tablet, three briquettes of a compressed sample, a second graphite tablet, a press washer, and a punch were placed in the matrix. Then the matrix was heated for three hours and allowed to stand for 20 minutes. 


\subsection{Mechanical tensile tests}

For tensile tests, two specimens from each bar were made of rods.

Table 5 Results of mechanical tensile testing of $\mathrm{Al}+$ TIM rods

\begin{tabular}{|c|c|c|c|c|c|}
\hline \multirow{2}{*}{ Bar number } & \multirow{2}{*}{ Chem. structure } & \multicolumn{3}{|c|}{ Tensile strength (MPa) } & \multirow{2}{*}{ Hardening (\%) } \\
\cline { 3 - 5 } & & Sample 1 & Sample 2 & The average & \\
\hline 0 & $\mathrm{Al}-$ powder & 127 & 126 & 126 & $\mathrm{~N} / \mathrm{A}$ \\
\hline 1 & $\mathrm{Al}+(3 \%) \mathrm{Al}_{18} \mathrm{Mg}_{3} \mathrm{Cr}_{2}$ & 129 & 132 & 131 & 3.3 \\
\hline 2 & $\mathrm{Al}+(3 \%) \mathrm{Al}_{18} \mathrm{Mg}_{3} \mathrm{Mn}_{2}$ & - & 139 & 139 & 9.7 \\
\hline 3 & $\mathrm{Al}+(3 \%) \mathrm{Al}_{11} \mathrm{Ti}_{4} \mathrm{Zn}$ & 133 & 130 & 131 & 3.8 \\
\hline 4 & $\mathrm{Al}+(3 \%) \mathrm{Al}_{66} \mathrm{Ti}_{25} \mathrm{Zn}_{9}$ & 124 & 126 & 125 & -1.1 \\
\hline
\end{tabular}

From Table 5 it can be concluded that the $\mathrm{Al}+(3 \mathrm{wt} \%)$ Al ${ }_{66} \mathrm{Ti}_{25} \mathrm{Zn} \mathrm{n}_{9}$ composite does not exhibit the necessary strengthening effect. Aluminum rods containing $3 \% \mathrm{Al}_{18} \mathrm{Mg}_{3} \mathrm{Cr}_{2}$ and $\mathrm{Al}_{11} \mathrm{Ti}_{4} \mathrm{Zn}$ slightly strengthen the matrix. A sample of $\mathrm{Al}+(3 \mathrm{wt} \%) \mathrm{Al}_{18} \mathrm{Mg}_{3} \mathrm{Mn}_{2}$ is released, which is almost $10 \%$ stronger than pure aluminum bar. It was at the rod of this chemical composition that one of the samples collapsed in the clamps along the thread. Both magnesium and manganese significantly increase the strength characteristics of aluminum, but both of them significantly embrittle the matrix (even when doped with a small amount). If we assume that the theory of the interaction of cast alloys is valid for composite materials "matrix + dispersed hardener", then such an increase in strength (and embrittlement) is theoretically justified.

\subsection{Microhardness}

Table 6 shows the results of microhardness measurements using a Hynistron TI 750 Ubi 1 Triboindenter scanning nanohardness tester. During the experiment, 7 measurements were carried out, two of which - the largest and smallest - were excluded from the calculation of the average value.

Table 6 The results of microhardness measurements of aluminum rods, dispersion hardened by intermetallic compounds

\begin{tabular}{|c|c|c|c|c|c|c|c|c|}
\hline & \multicolumn{7}{|c|}{ Microhardness, HV } & \multirow{2}{*}{$\begin{array}{c}\text { The increase in } \\
\text { hardness } \%)\end{array}$} \\
\hline $\begin{array}{c}\text { Bar } \\
\text { number }\end{array}$ & Mens. 1 & Mens. 2 & Mens. 3 & Mens. 4 & Mens. 5 & Average & TIM & - \\
\hline 0 & 39.0 & 38.5 & 38.4 & 38.9 & 38.9 & 38.7 & - & 463 \\
\hline 1 & 43.2 & 43.6 & 44.2 & 42.8 & 43.8 & 43.5 & 463 & 12.3 \\
\hline 2 & 48.5 & 64.5 & 43.0 & 45.9 & 49.6 & 50.3 & 406 & 29.8 \\
\hline 3 & 61.0 & 59.5 & 56.0 & 53.2 & 59.1 & 57.8 & 568 & 49.1 \\
\hline 4 & 40.8 & 42.2 & 43.9 & 43.9 & 40.9 & 42.3 & 393 & 9.3 \\
\hline
\end{tabular}

After evaluating the results of Table 5 and Table 6, one can observe both the absence of hardening and the smallest increase in microhardness of sample 4. A slight increase in the strength characteristics of sample 1 is also consistent. Sample 3 showed the greatest increase in microhardness, but a slight increase in tensile strength. In terms of the combination of strength properties, the second sample proves better than the others - a relatively good increase in microhardness and an increase in tensile strength by almost $10 \%$. 


\section{CONCLUSION}

The following conclusions can be drawn from the research work:

1) Five samples were obtained by hot extrusion: 1 pure aluminum sample and 4 composite $\mathrm{Al}$ rods $+3 \%$ $\mathrm{Ml}$ at $400{ }^{\circ} \mathrm{C}$ and drawing coefficient 9 . The microhardness index of all dispersively hardened samples increases. The best reinforcing composition (available) is $\mathrm{Al}_{18} \mathrm{Mg}_{3} \mathrm{Mn}_{2}$. The introduction of $3 \%$ of which into the aluminum matrix increases the microhardness by $30 \%$.

2) Pictures of the microstructure of the cross section, in which the intermetallic inclusions are distributed evenly, indicate the homogeneity of the matrix and hardener.

3) It is supposed that during further research it is possible to change the percentage of the MI phase in the Al matrix (both upward and downward), increase the dispersion, find the optimal exposure time and also increase the drawing coefficient.

\section{REFERENCES}

[1] TROTSKY, M., PETROVICH, S., ZAMOZDRA, M., WANG, Q.S. Study of the phase evolution during the mechanical alloying of the TiN-TiC-TiB2-TiO 2 system. Materials Today: Proceedings, 2020.

[2] GONCHAROV, I.S., RAZUMOV, N.G., SHAMSHURIN, A.I., WANG, Q.S. Effect of the mechanical alloying and spark plasma sintering on microstructure. Phase composition and chemical elements distribution of $\mathrm{Nb}$-Si based composite. Key Eng. Mater. 2019, vol. 822, pp. 617-627.

[3] RAZUMOV, N.G., POPOVICH, A.A., GRIGOR'EV, A. V., SILIN, A.O., GONCHAROV, I.S. Morphology of highstrength heat-resistant steel powder for machines for additive production from shavings. Met. Sci. Heat Treat. 2019, pp. 1-5.

[4] GONCHAROV, I.S., RAZUMOV, N.G., SILIN, A.O., OZERSKOI, N.E., SHAMSHURIN, A.I., KIM, A., WANG, Q.S., POPOVICH, A.A. Synthesis of Nb-based powder alloy by mechanical alloying and plasma spheroidization processes for additive manufacturing. Mater. Lett. 2019. DOI: 10.1016/j.matlet.2019.03.014

[5] POPOVICH A.A., RAZUMOV, N.G. Dissolution of alloying elements and powder materials Fe-18Cr-8Ni-12Mn-xN during mechanichal alloying. Adv. Mater. Lett. Dec. 2014, vol. 5, no. 12, pp. 683-687.

[6] POPOVICH, A. A. et al. Mechanochemical synthesis of high-alloyed powder alloys of the Fe-Cr-Ni-Mn-N system. Russ. J. Non-Ferrous Met. Nov. 2013, vol. 54, no. 6, pp. 508-512. 